ISSN1027-5495. Functional Materials, 23, No.2 (2016), p. 243-248

doi:http://dx.doi.org/10.15407/fm23.02.243

(C) 2016 - STC “Institute for Single Crystals"

\title{
Process and property of hot-rolled stainless steel/carbon steel cladding bar
}

\author{
Zhining Jia, Yanan Gao \\ Chengde Petroleum College, Chengde 067000, Hebei, China
}

Received September 30, 2015

\begin{abstract}
To study the process and property of hot-rolled stainless steel/carbon steel cladding bar, a rational pass system is designed for rolling and the bonding strength between the stainless steel cladding and carbon steel core was investigated by using shearing test and bending test. Then, the bonding interface, element diffusion and shearing fracture surface were analyzed by applying optical microscope, EDS and SEM. The results show that the thickness distribution of stainless steel shell is homogeneous; the metallurgical bonding between the two metals is formed after the third pass rolling and the shearing strength of the interface is more than 307 $\mathrm{MPa}$. At the same time, the bending property of the bar displays well. The interface region is clearly divided into stainless steel zone, transition zone and carbon steel zone. Element diffusion occurs at the interface that the Fe of carbon steel diffuses into stainless steel and the $\mathrm{Cr}$, Ni, Mn of stainless steel diffuse into carbon steel. It makes the formation of the transition zone with 20 $\mu \mathrm{m}$ in width in carbon steel and the total width of diffusion zone is $30 \mu \mathrm{m}$. Shearing strength of the interface after the sixth pass rolling is higher than the carbon steel substrate and the shearing fracture occurs in the carbon steel.
\end{abstract}

Keywords: cladding bar; stainless steel; rolling; pass design; element diffusion

Разработана рациональная система для прокатки, исследована прочность сцепления между облицовкой из нержавеющей стали и ядром из углеродистой стали путем испытаний на сдвиг и изгиб. Проанализированы поверхность сцепления, диффузия элементов и поверхность разрыва при сдвиге с применением оптической микроскопии, ЭДС и СЭМ. Результаты показывают, что распределение толщины оболочки из нержавеющей стали является однородным. Сцепление между этими двумя материалами формируется после третьего прохода прокатки, а прочность сцепления межслоевой границы составляет более 307 МПа. Изгибные свойства бруска оказываются хорошими. Область сцепления четко разделяется на зону нержавеющей стали и зону углеродистой стали. Дифффузия элементов возникает на границе, причем $\mathrm{Fe}$ из углеродистой стали диффбундирует в нержавеющую сталь, a $\mathrm{Cr}, \mathrm{Ni}, \mathrm{Mn}$ из нержавеющей стали дифффундирует в углеродистую сталь. Это приводит к формированию переходной зоны шириной 20 мкм в углеродистой стали, ширина дифффузионной зоны составляет 30 мкм. Прочность на сдвиг межслоевой границы после шести проходов прокатки становится выше, чем для подложки из углеродистой стали, разрушение сдвига возникает в углеродистой стали.

Отримання i властивості облицювальних стрижнів, отриманих гарячим плющенням неіржавіючої сталі на вуглецевій сталі. Джининг Яia, Янан Гао

Розроблена раціональна система для плющення, досліджена міцність зчеплення між облицюванням 3 неіржавіючої сталі і ядром з вуглецевої сталі шляхом випробувань на зрушення і вигин. Проаналізовані поверхня зчеплення, дифузія елементів і поверхня розриву при зрушенні із застосуванням оптичної мікроскопії, ЭДС і СЕМ. Результати показують, що розподіл товщини оболонки з неіржавіючої сталі е однорідним; Зчеплення між цими двома матеріалами формуеться після третього проходу плющення, а міцність зчеплення міжшарової межі складає більше 307 Мпа. Вигинисті властивості бруска виявляються хорошими. Область зчеплення чітко розділяеться на зону неіржавіючої сталі i зону вуглецевої сталі. Дифузія елементів виникає на межі, причому Fe з вуглецевої сталі дифундує в неіржавіючу сталь, а $\mathrm{Cr}, \mathrm{Ni}, \mathrm{Mn}$ з неіржавіючої сталі дифундує у вуглецеву сталь. Це приводить до формування перехідної зони шириною 20 мкм у вуглецевій сталі, а повна ширина дифузійної зони складає 30 мкм. Міцність на зрушення міжшарової межі після шести проходів плющення стае вищою, ніж для підкладки з вуглецевої сталі, руйнування зрушення виникає у вуглецевій сталі. 


\section{Introduction}

Because of climate and human factors, the corrosion of reinforcing steel bar has become one of the important reasons of premature deterioration of concrete buildings and infrastructure [1-3]. Using stainless steel bar will solve this problem, to some extent $[4,5]$. However, stainless steel bar cannot be widely used due to its high price. Therefore, using various ways to fabricate stainless steel/carbon steel cladding material or other cladding materials come into being $[6,7]$. Stainless steel/carbon steel cladding bar, which is made up of corrosion resistant stainless steel outer layer and carbon steel core, is a new material used in construction. It takes account of the corrosion resistance of stainless steel and the mechanical properties of carbon steel as well as the lower cost compared to the homogeneous stainless steel bar.

For bimetallic bar, more attention is paid to the research of the soft metal bar by extrusion $[8,9]$. For the production of stainless steel/carbon steel cladding bar, hot rolling is the most economical and efficient method to make the two metals be metallurgical bonding. H. Dyja and others created a mathematical model to simulate the metal flow of bimetallic bar in rolling process, and summarized the rolling technology of bimetallic bar [10,11].

STELAX Company produces cladding bar under the trade name NUOVINOX. The composite workpiece consists of two materials. The cladding is welded stainless steel tubes, and the core is made of scrap iron. After fabrication processing and pressure processing, it is hot rolled as the final process [12]. The manufacturer (SMI-Texas) produces cladding bar utilizing the Osprey Process, which involves blasting the molten stainless steel with nitrogen onto the heated carbon steel. After cooling slightly, it is feed into continuous hot rolling mill [13]. As to the applied research of rolling stainless steel/carbon steel cladding bar, there is no relevant report in China.

Metallurgical bonding between the two materials is a key indicator of the property of cladding bar. Due to the different deformation resistance and extension of the two metals, it is difficult to guarantee the bonding strength and compatible deformation. So, it is important to know how to roll the qualified bimetallic bar successfully. As the metallurgical bonding between the two materials at the first few passes in the rolling process, it is especially important to study these passes. Therefore, experimental study is carried out for the process and property of hot-rolled stainless steel/carbon steel cladding bar, and a rational pass system is designed. In the rolling process, the deformation
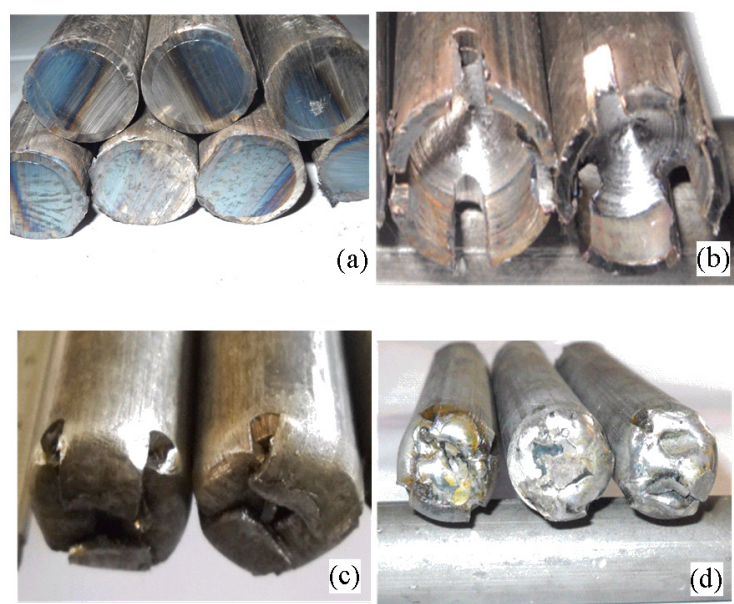

Fig. 1 Process of specimen preparation

characteristics of the two metals and the thickness distribution of stainless steel and bonding strength are observed. Also, the interface state, fracture morphology and the diffusion of elements are analyzed by using optical microscopy, SEM and EDS. The bonding mechanism of metals is discovered. At last, the feasibility of hot rolling cladding bar by using this system is verified, and it will offer advice to industrial production of stainless steel/carbon steel cladding bar.

\section{Experimental}

\subsection{Specimen prepartion}

Specimen is made up of type 304 stainless steel pipe and Q195 carbon steel core. The initial diameter is $22 \mathrm{~mm}$ for stainless steel shell and $17.2 \mathrm{~mm}$ for carbon steel core respectively. The wall thickness of pipe is $2 \mathrm{~mm}$. There is a coating of oxide or filth, which attaches to the metal surface inevitably and influences the bonding of two metals. So, it is important to clean the metal surface. The inner surface of stainless steel pipe is polished by sandpaper and carbon steel surface is descaled by a wire brush. These also create surface roughness and make the virgin metal surface exposed. After inserting the carbon steel core into the stainless steel pipe, the composite bar is drawn by using drawing machine, and it makes a tight fit between the two metals. Then the drawn bar is cut to specimens, which are $150 \mathrm{~mm}$ for length, $20 \mathrm{~mm}$ for diameter and $1.8 \mathrm{~mm}$ for wall thickness. Due to different thermal expansion, interstices maybe appear between the two metals when heated. In order to prevent the bar from being oxidized, the ends of specimens are welded as shown in Fig. 1.

\subsection{Pass system}

Pass system is a basic aspect for rolling stainless steel/carbon steel cladding bar successful- 

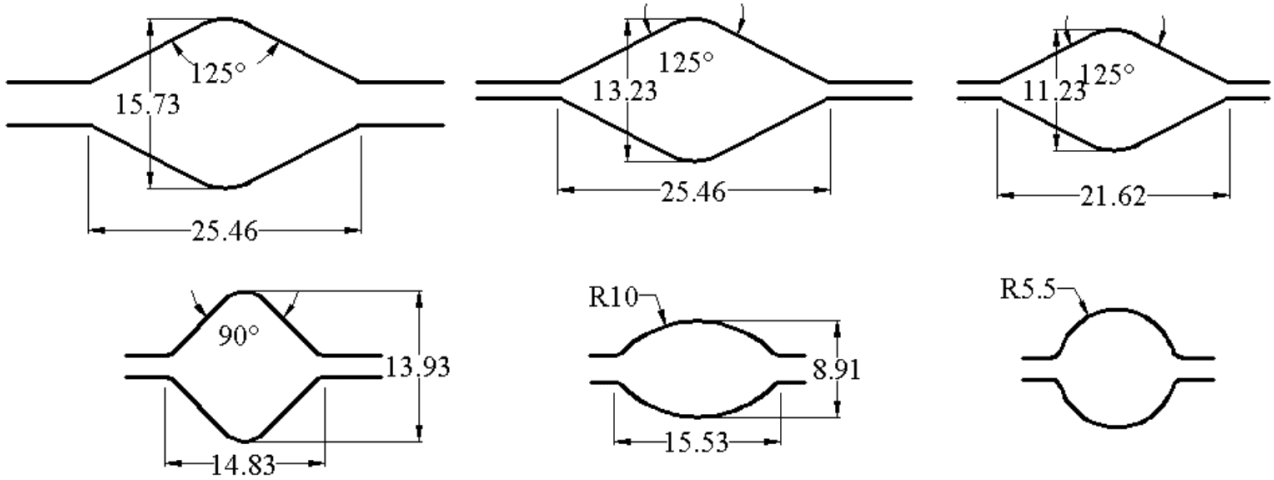

Fig. 2 Shape and dimensions of grooves

ly. Proper pass system helps to make the metal flow reasonable and prevent the emergence of complex stress state, which might cause defects in the cladding, such as non-uniform thickness, micro-damage and wrinkles, etc. Moreover, the optimal pass system can increase the contact stress of the interface and promote the metallurgical bonding of the two metals.

The role of passes is to make the metallurgical bonding appear quickly under the large rolling pressure, plastic strain and interfacial stress. So the lengthening coefficient and stability of passes are necessary. Experiment adopts autonomous rational pass system. As shown in Fig. 2, six passes are used in the diamond-diamond-diamond-square-oval-round system for experiment. The roller's diameter is $220 \mathrm{~mm}$, and speed is $0.1 \mathrm{r} / \mathrm{s}$. Specimens can be rolled after being heated for $30 \mathrm{~min}$ at $1150{ }^{\circ} \mathrm{C}$ in a muffle furnace.

\subsection{Mechanical test}

The bonding strength between stainless steel cladding and carbon steel core is a key judgment standard for evaluating the quality of cladding bar. A shearing test is used to measure the strength. The specimen shown in Fig. 3 is obtained along the axis of cladding bar. Through measuring the length and width of the binding region, the contact area can be calculated. In the experiment, a WD-1 universal material tester is used. The Schema of shearing test is shown in Fig. 4. The shearing forces in three positions around the circumference of cladding bar are measured. Then the mean shearing force can be get. The maximum shearing strength can be calculated according to the formula,

$$
\tau_{b}=F / A
$$

Where $\tau_{b}, F$ and $A$ are the maximum shearing strength, shearing force and the area of the bonding region respectively.

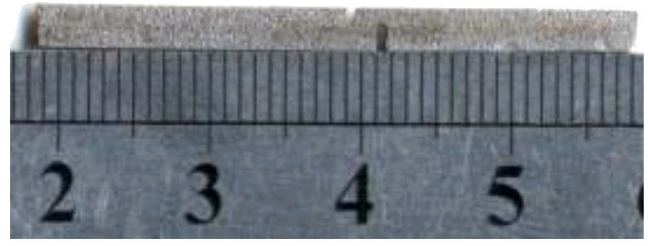

Fig. 3 Photo of shearing test specimen

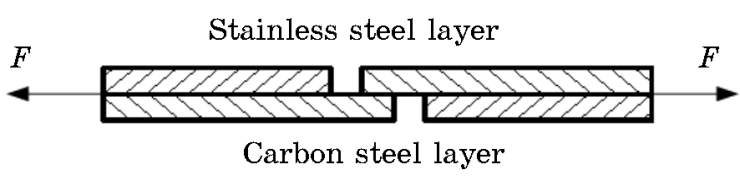

Fig. 4 Schema of shearing test

\section{Results and discussions}

\subsection{Shape and Size}

After rolling, the surface of cladding bar is burnished and acid cleaned to remove the surface oxide layer. The bar rolled by each pass is shown in Fig. 5. It can be seen that the lateral spread of bars is uniform after the first two passes rolling but broader ends with narrower middle part after the third pass, and the middle proportion increases with the pass continuing. Due to the existence of oxygen, the both ends of workpieces would be oxidized during rolling process. Meanwhile the extension of the core is easy, so the contact stress is little and relative sliding between two metals appears, then the metallurgical bonding cannot be formed. These are two main reasons why the lateral spread at ends is larger than it at the bonding part. No bonding appear between the two metals during the first pass rolling, so there is no significant difference between the ends and the intermediate section in the lateral spread. In the second pass rolling, the extension coefficient and the contact stress of the interface at the top increases, thus the bonding of two metals occurs in this region. However, the lateral spread mainly oc- 


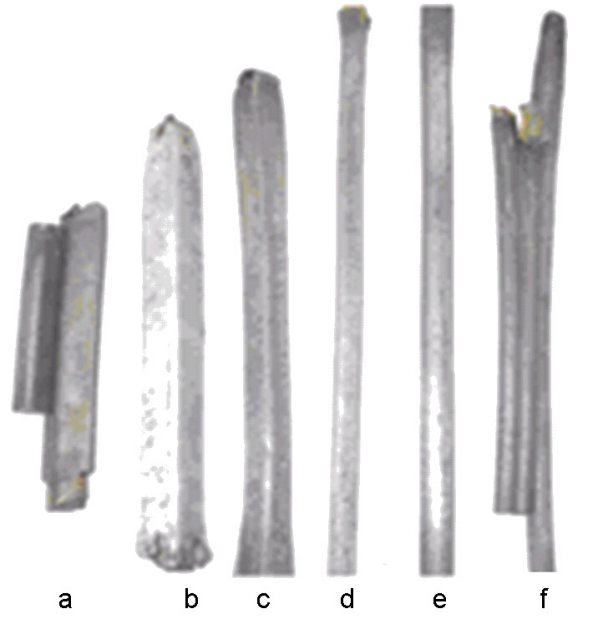

Fig. 5. Photo of workpieces after each passes (a) after 1th pass, (b) after 2th pass,(c) after 3rd pass,(d) after 4th pass, (e) after 5th pass, (f) after 6 th pass

curs at the backward slip zone where bonding has not generated, so the width of workpiece is uniform in this pass. Metallurgical bonding appears at the reduction side in the middle of the rod in the second pass, so the deformation of the materials is compatible and there is no slip in this region during the third pass rolling. So, the middle part is narrower than the ends as is shown in Fig. 5.

The sizes and the morphology of cross-sections of six rolled samples are shown in Fig. 6. The carbon steel cores of samples are etched by $4 \%$ nitric acid alcohol after metallographic polishing. Because the corrosive action of nitric acid alcohol on 304 stainless steel is not obvious, it is easy to make a distinction between the stainless steel and carbon steel and observe the uniform distribution of the stainless wall thickness. The interfaces of two metals are clear and smooth. The two metals are tightly combined and there is no wrinkle or cracks. It proves the rationality of the passes, and there is no stress concentration in the rolling process.

\subsection{Mechanical properties}

The result of shearing test can be seen in Fig. 7, which shows the changing trend of the bonding strength between two metals with the changing of passes. After the first pass, the shearing strength of the interface is $0 \mathrm{MPa}$, so it proves that there is no metallurgical bonding appearing even mechanical bonding. Then, the average shearing strength jumps to $157 \mathrm{MPa}$ after the second pass, and up to $307 \mathrm{MPa}$ after the third pass. In the following passes, it increases slowly and reaches about $333 \mathrm{MPa}$ at the last pass.

The metallurgical bonding between the two materials is formed from scratch in during the first three passes. Due to the little elongation coefficient of the first pass, interface contact stress of reduction side cannot make metallurgical bonding formed. But in the second pass with a larger elongation coefficient, the metallurgical bonding forms in the reduction side. After the third pass, the bonding occurs at the spread side of the previous pass as well. At this moment, metallurgical bonding appears in the circumferential direction of the contact interface. Therefore, the shearing strength of the third pass is 2 times larger than the second pass. After this pass, the area of the metallurgical bonding region increases slowly, so it can be seen the slowly increasing of shearing strength.

Bending test on rolled specimens is carried out. The middle part of specimens is split along the axis. Carbon steel core is defined as the inside and stainless steel layer as the outside respectively. There are three bending types, bending $180^{\circ}$ inward, bending $180^{\circ}$ outward and bending $180^{\circ}$ laterally, as is shown in Fig. 8. In the case of inward bending, metal at the bended position gets to broaden under pressure and stainless steel cladding becomes thicker and eversible. In the case of outward bending, metal gets to narrow under the tensile force, and stainless steel cladding becomes thinner. In the case of lateral bending, on the inner side, the cladding is under pressure and becomes thicker; on the out side, the cladding is under tensile force and becomes thinner. It can be seen that no matter tensile stress or compressive stress appears in the interface, there is no

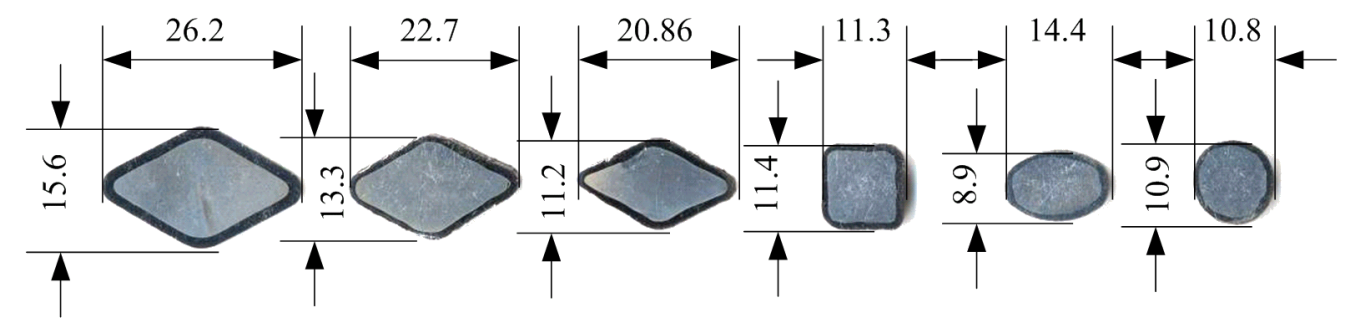

Fig. 6 Size and morphology of cross-section 


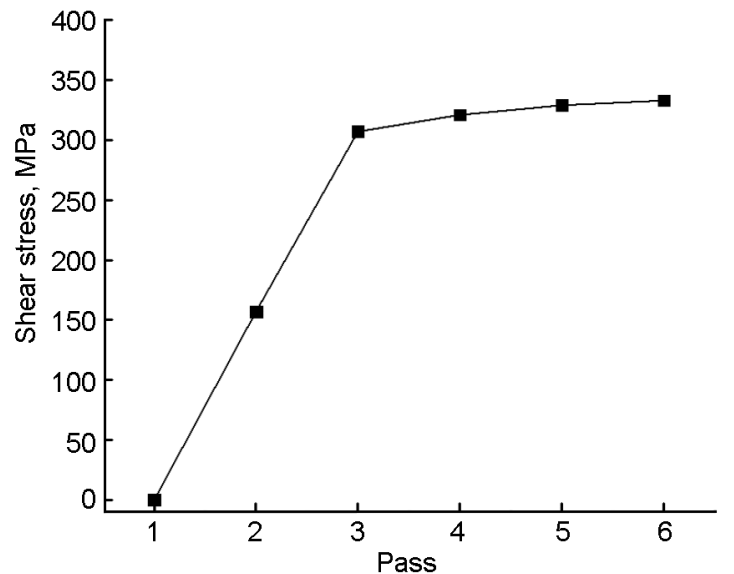

Fig. 7. The trend of shearing strength with the pass.

crack or tear. Both the two metals display the same tensile strain and compressive strain.

\subsection{Interface Analysis}

After six passes rolling, the metallograph of the bonding region of cladding bar is shown in Fig. 9. It can be seen that there are three clear zones, stainless steel zone, transition zone and carbon steel zone. The region with grains in bottom left part is the carbon steel zone. The line in the middle consisting of intermittent dots is the original contact interface, and the top right region, which is not corroded by nitric acid alcohol, is the stainless steel zone. The region between this line and boundary line of grains is the transition zone, which is $20 \mathrm{Mm}$ in width. By observing the line of demarcation between stainless steel and carbon steel, these black spots should be intermittent small holes, which may be the incomplete contacting rough surfaces or the residual impurities in the process of preparing the workpieces. There is no obvious contact trace in the interface between stainless steel and carbon steel except these small holes, which proves that the metallurgical bonding has formed in these positions.

In order to investigate Element distribution of $\mathrm{Fe}, \mathrm{Cr}, \mathrm{Mn}, \mathrm{C}, \mathrm{Ni}$ in the transition zone, where is not corroded, EDS is introduced. The line scanning results are shown in Fig.10. The vertical line, whose left and right are the carbon steel zone and stainless steel zone, represents the interface. Element diffusion near the interface can be seen distinctly. As is shown in the picture, Fe diffuses to stainless steel from carbon steel, which makes the content of $\mathrm{Fe}$ in carbon steel decreasing but increasing in stainless steel. At the same time, $\mathrm{Cr}, \mathrm{Mn}$, Ni diffuse to carbon steel from stainless steel, which makes the content of these elements in stainless steel decreasing. It can be measured that the diffusion distance of carbon steel is about $20 \mu \mathrm{m}$,

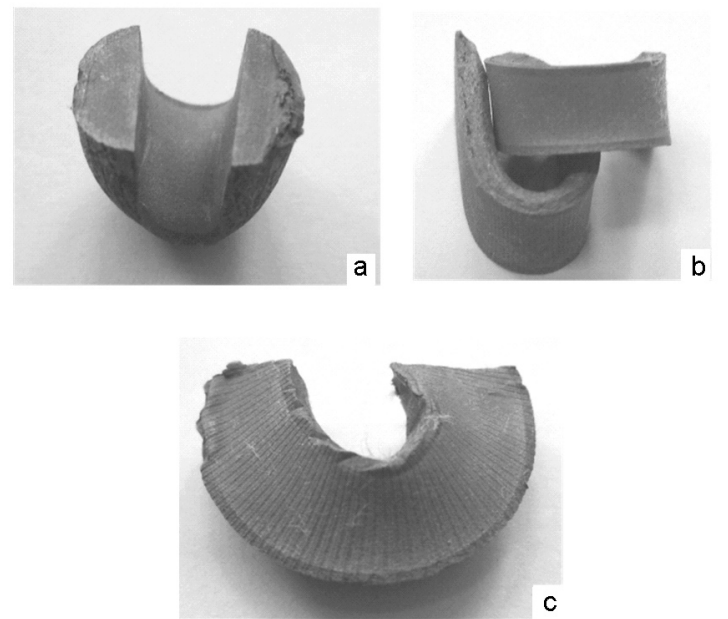

Fig. 8. Photos of bending test. (a) Bending $180^{\circ}$ inward; (b) Bending $180^{\circ}$ outward; (c) Bending $180^{\circ}$ laterally.

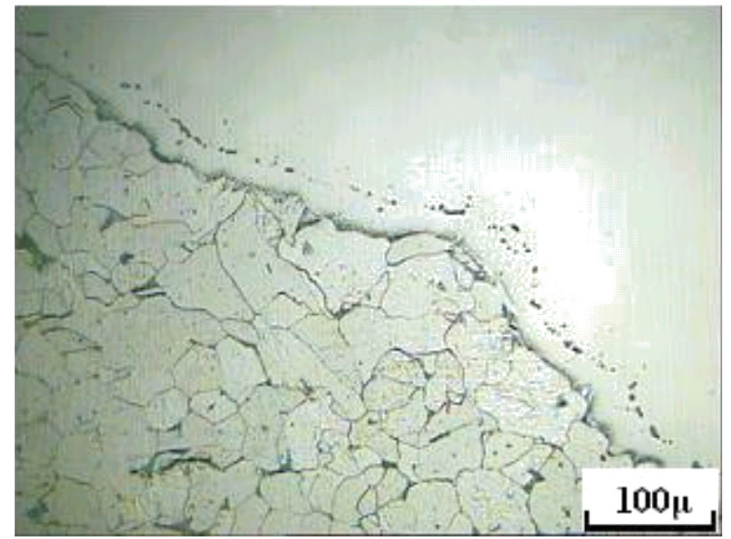

Fig. 9. Metallograph of bonding region

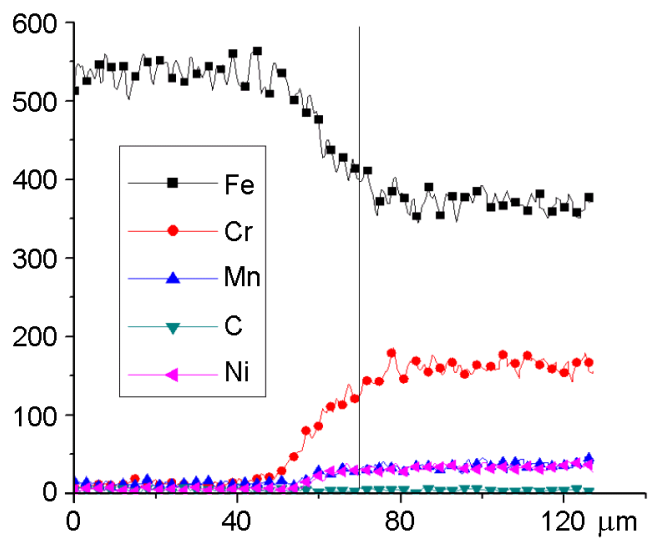

Fig. 10. EDS line scanning curves of bonding region

which is as much as the width of the transition region in Fig. 9. It is the reason that there is no corrosion in this zone. The diffusion distance in stainless steel is about $10 \mu \mathrm{m}$. Therefore, the total width of diffusion zone on both sides of 

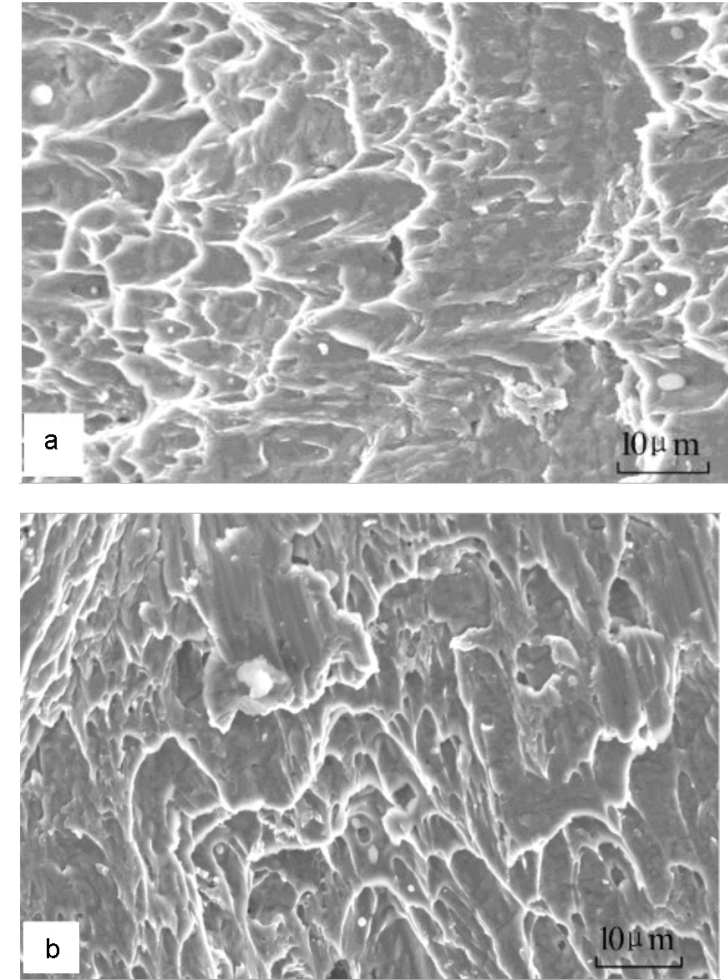

Fig. 11. SEM micrographs of fracture surface (a) Carbon steel, (b) Stainless steel

the interface is $30 \mu \mathrm{m}$. Since the content of C in stainless steel is similar as in Q195 and the C concentration gradient of both sides is very small, there is no significant diffusion occurring according to the Fick diffusion law.

The shearing fractograph of the sixth pass is shown in Fig. 11. Fig. 11(a) shows the side of the carbon steel and Fig. 11(b) shows the side of the stainless steel. It can be seen that the morphology of both sides is very similar and there are typical ductile dimples, which inclines with large leaning angle towards to a specific direction. The inclination as shown is occurred because of the larger shearing sliding of the shearing plane. Due to the strength of stainless steel is higher than carbon steel, it can be estimated that the material of dimple on stainless steel side is carbon steel and shearing fracture appears on carbon steel. In addition, based on the discussed above, it can be concluded that the interface strength is higher than carbon steel and metallurgical bonding has happened between the two metals.

\section{Conclusions}

By rational pass system, stainless steel/carbon steel cladding bar is hot rolled successfully, and it can be seen clearly that the wall thick- ness of the bar is even, the contact of the two metals is compact and there is no defect find.

After the first pass, the metallurgical bonding of stainless steel and carbon steel cannot be achieved. There is only half of the interface having achieved metallurgical bonding after second pass rolling, and the full metallurgical bonding appears after the third pass. The shearing strength of the interface is more than $307 \mathrm{MPa}$. There is no crack appearing when the specimens are inward bended, outward bended and lateral bended, and it shows that the bending performance of cladding bar is satisfactory.

The bonding region near the interface of cladding bar can be divided into three zones: stainless steel zone, carbon steel zone and transition zone. Elements diffusion has happened near the interface. Fe in carbon steel diffuses $10 \mu \mathrm{m}$ toward stainless steel and $\mathrm{Cr}, \mathrm{Mn}, \mathrm{Ni}$ in stainless steel diffuse $20 \mu \mathrm{m}$ toward carbon steel, which makes the transition region display clear. The total width of diffusion zone is $30 \mu \mathrm{m}$.

The shearing strength of interface is higher than carbon steel substrate. Therefore, the shearing fracture appears in carbon steel and metallurgical bonding has formed

\section{References}

1.M.Mancio, J. Y. Zhang, P. J. M. Monteiro, Aci Mater. J., 21(2), 18, 2004.

2.S. Barella, C. Mapelli, R. Venturini, Metallurg Scie. Tecnol, 23(1), 19, 2005,

3.M. Moreno, W. Morris, M. G. Alvarez, et al.,, Corrosion Science, 46(11): 2681, 2004.

4.S. R. Moraes, D. Huerta-Vilca, A. J. Motheo,. Progr. Org.Coat., 48(1), 28, 2003.

5.M. Nasresfahani, M. Pourriahi, A. Motalebi, et al., Anti-Corros. Meth.Mater., 61(1),1, 2014

6.Patent United States, US8978430 B2, 2015.

7.C. P. Paul, H. Alemohammad, E. Toyserkani, et al., Mater.Scie. Eng., A 464(1-2), 170, 2007,.

8.A. R. Eivani, A. K.Taheri, Mater. Lett., 61(1920), 4110, 2007,.

9.A. Khosravifard, R. Ebrahimi, Mater. Design, 31(1), 493, 2010.

10. Dyja H, Mroz S, Milenin A, Lesik L., The 44th Mech.Working Steel Proc. Conf. 8th Steel Rolling Intern. Conf., Orlando, 2002, 653.

11. P. Szota, H. Dyja, J.Achiev. Mater. Manuf. Engin., 25(1), 55, 2007.

12. G. Markeset, S. Rostam, O. Klinghoffer. Guide for the use of stainless steel reinforcement in concrete structures. Oslo: Norwegian Building Research Institute. Project Report, 2006.

13. M. C. William, E. D. F. Duke, J. J. Kellar, et al. Stainless steel clad rebar in bridge decks. Rapid City: South Dakota Department of Transportation Office of Research, Final Report, 2001. 